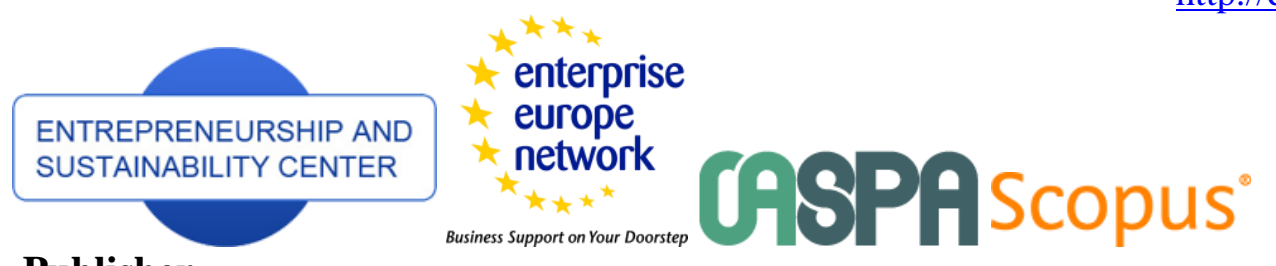

Publisher

$\underline{\text { http://jssidoi.org/esc/home }}$

D Clarivate

Analytics

\title{
ECONOMIC ASPECTS OF THE CREATION OF MOBILE UNITS PROVIDING EVERYDAY SERVICES IN OFF-ROAD CONDITIONS IN WESTERN SIBERIA
}

\section{Oksana Viktorovna Shumakova', Marina Nikolaevna Gapon², Oleg Anatolyevich Blinov², Vitaly Yuryevich Epanchintsev ${ }^{4}$, Yury Ivanovich Novikov ${ }^{5}$}

\author{
1,2,3,4,5 Omsk State Agrarian University named after P.A. Stolypin, Institutskaya pl. 1, 644008, Omsk Russian Federation \\ E-mails: ${ }^{1}$ oleg_blinov_2001@mail.ru*
}

Received 20 February 2018; accepted 16 May 2018; published 30 June 2018

\begin{abstract}
This article proposes a solution to alleviate socio-economic problems faced by rural areas in Western Siberia, such as the municipal districts of Omsk region, which are seasonally cut off from national transport infrastructure due to extreme climatic conditions. Specifically, it explores issues related to the provision of basic, everyday services in such regions. Based on an opinion poll which identified a significant need for better provision of everyday services such as hairdressing salons, repair shops and so on in remote regions of Western Siberia, the authors propose a model for an investment project to develop mobile units to provide such services. The costs of setting up such units and the period of time required to recoup those costs, as well as the benefits they will bring to the societies in question, are examined in depth. The provision of government financial support for setting up businesses engaged in this kind of social enterprise is also explored.
\end{abstract}

Keywords: Western Siberia; Rural territories; Off-road conditions; Mobile Units

Reference to this paper should be made as follows: Shumakova O. V.; Gapon M. N.; Blinov O. A.; Epanchintsev V. Y.; Novikov Y. I., 2018. Economic aspects of the creation of mobile units providing everyday services in off-road conditions in Western Siberia, Entrepreneurship and Sustainability Issues, 5(4): 736-747. https://doi.org/10.9770/jesi.2018.5.4(4)

JEL Classifications: O10, O13

\section{Introduction}

The service industry plays an important role in supporting populations and in the socio-economic development of countries throughout the civilized world. The social importance of everyday services is highlighted by the fact

\footnotetext{
* Research was supported by Russian Foundation for Basic Research according to the research project № 18-410-550024

"Research of the system of indicators of the level and quality of life of the rural population, allowing to evaluate the results of social development of rural areas of the Omsk region".
} 
that services take a share, on average, of $31 \%$ of the US consumer budget; this figure is $37 \%$ in the UK, $41 \%$ in Sweden $41 \%$, and about $13 \%$ in Russia (Shainyan, 2007). Transport is an essential part of the industrial and social infrastructure (Tvaronavičienè 2018). The low level of development of Russia's transport infrastructure can be explained not only by a lack of funding, but also by the severe natural and climatic conditions experienced by most parts of its territory. As a result, the majority of Russian regions are described as having seasonal problems with off-road conditions, in that many villages and even entire territories are not connected by ground transportation to the rest of the country for much of the year. The only alternative available in this case is air transportation, which also requires certain infrastructure. Taken together, these problems lead to a decrease in the level of satisfaction among rural populations with the way in which their everyday needs and social requirements are met during such times.

Analysis of condition of rural areas in Omsk region indicates at its low socio-economic development. Particularly, there is a decrease of population because of a significant migration from the region due to the deterioration of living conditions (Table 1).

Table 1. Indicators of living standards of the rural population of the Omsk region

\begin{tabular}{|c|c|c|c|c|c|c|}
\hline Indicators & \multicolumn{5}{|c|}{ Years } & $\begin{array}{l}2015 \text { to } \\
2011, \%\end{array}$ \\
\hline $\begin{array}{l}\text { The ratio of the average wage in the countryside to the } \\
\text { wages of the urban population, } \%\end{array}$ & 59,6 & 59,8 & 60,8 & 62,8 & 64,7 & 5,1 \\
\hline The number of cultural and community institutions & 1079 & 1084 & 1079 & 1059 & 1051 & 97,4 \\
\hline
\end{tabular}

There is a need for the state to take a pro-active stand on creating the conditions for socio-economic development: to improve the quality of transport services, to reduce the total expenses for those dependent on transport, to improve the national transport system's competitiveness, to strengthen innovation, and to encourage socially and ecologically oriented development within the transport industry (On approval of the state program of Omsk region "Development of transport system of the Omsk region", \#262-P, 2013; On approval of the state program of the Russian Federation "Development of the transport system" \#319, 2014).

Public services enterprises in industrialized countries use the latest technology for providing services and regularly modify the existing equipment in accordance with developments in science and technology (Frolova and Rogach, 2017).

The most profitable areas of consumer services in the US and Europe are dry cleaning and laundry, as well as health and beauty salons. Franchising is one of the most common ways of network business development (Shainyan, 2007).

In Russia, the service sector is developing in large cities. In small areas, especially in those with low infrastructure development, the public and private partnerships need to be developed. The assistance of state structures and funds in preparation of socially significant projects, their partial investment ensures development of comfortable life for the population. 


\section{Analysis of recent publications on the issue}

Aspects of the development of social infrastructure in rural Russia which experience off-road conditions are noted in the works of (Akhmetshin et al., 2017; Akhmetshin and Osadchy, 2015; Shumakova et al., 2012; Poltorykhin et al., 2015; Nardin et al., 2015; Shumakova et al., 2015). On the strategy of sustainable development of rural territories of the Russian Federation for the period through to 2030 \#151-r., 2015; On general principles for the organization of local government in the Russian Federation, \#131, 2003). S. Marsat and B. Williams note that in the UK investors are concerned about the disclosure of social information given the historical importance attached to social issues in the country. This is consistent with other recent studies which show that investors around the world are currently concerned about the social activities of the companies they invest in (Marsat and Williams, 2014, p. 11).

Issues of corporate social responsibility are given a lot of attention in many countries; for example, the European Commission has highlighted the responsibility of enterprises for their impacts on society (A Renewed EU Strategy 2011-14, 2011), as reflected in their Green Paper on "Promoting a European framework for corporate social responsibility" (GREEN PAPER: Promoting a European Framework for Corporate Social Responsibility, 2001). The companies should focus exclusively on maximizing shareholders' wealth has long been the dominant assumption in economics studies (Shannon et al., 2009, p. 143). However, taking social responsibility into consideration in the provision of everyday services is of interest because it suggests that firms are motivated to make decisions that do not always clearly maximize the wealth of the owners.

D.V. Moser and P.R. Martin note that the activities in the field of everyday services meet the needs of a broad group of stakeholders, not only the business owners (Moser and Martin, 2012, p. 798).

Some foreign authors, such as Wegren S.K. (2016), Velikii, P.P., Morekhina, M.Iu. (2006) and Granberg L. (2016), link the unsatisfactory quality of social and domestic services in rural areas with the lack of support from the state for the agro-industrial complex, since the agribusiness enterprises are the main places of work in the village (Glass and O'Brien, 2016), which in turn undermines the country's food security (Wegren et al., 2017; Wegren et al., 2016; Svetlanská et al., 2018).

Meanwhile, the economic aspect of the formation of mobile units providing social and everyday services in offroad conditions is understudied and remains open.

The purpose of this study is to develop activities aimed at improving transport infrastructure to meet the everyday needs of rural populations in off-road conditions, including the formation of projects investing in the organization of mobile units which can provide everyday services.

The subject of research. Tarsky Municipal District of the Omsk region with the district center in the city of Tara is a typical representative of the northern areas of the region. The climate here is sharply continental. The average annual air temperature is zero degrees Celsius. Rarely the weather reaches an absolute minimum in the winter minus 45 , and a top maximum in the summer - plus 45 degrees Celsius.

The main industries are agriculture, forestry and timber industry. The biggest share of economic entities operating in these sectors is small and medium-sized businesses.

The distance from the district to the regional center - $302 \mathrm{~km}$. Area of Tarski district is 15,600 sq. km. 45,600 people live in Tarski district. There is a natural decrease, the population in $2014-45,832$ people, in 2015 45682. Moreover, $42.3 \%$ of the population lives in rural areas. These areas include one urban settlement, which comprises three communities and 21 rural settlement, which include 73 communities. 
With a lack of district budget, which is $939,9 \mathrm{~m}$. rub. in 2015 , the social sphere is prioritized for the Administration.

\section{Materials and methods of study}

The goals and objectives of the study were achieved through the following scientific methods: economic and statistical, abstract and logical, design and constructive, as well as the methods of expert evaluations, microeconomic analysis of the economic phenomena and processes, and other methods of socio-economic research.

The provisions of the management theory, economic theory, statistical analysis, microeconomic forecasting were applied in the work. The works of well-known economists, legal acts regulating the sustainable development of rural areas, statistical materials and Internet resources were used in the study.

In particular, in order to evaluate household and social needs of the population in rural areas carried out an opinion poll among the population Tarski district of the Omsk region. Authors of the article with use of expert evaluation formed a list of 26 questions with many possible answers including:

- Note the presence of facilities in the territory of rural settlement (health, education, culture and arts, physical culture and sports, trade and public catering, consumer services, telecommunications, transport infrastructure, highways);

- Are you satisfied with the quality of (transport services, roads, heating, water, electricity, gas);

- How do you rate the conditions (teaching in schools, education of children in pre-school institutions, health care, cultural services, habitation);

- How do you rate the level of (supply of food and industrial goods, consumer services, the availability of public transport);

- Which factors, in your opinion, have the greatest influence on the development of social infrastructure: (State agricultural policy, the level of development of agricultural production, location of rural areas over the location of cities, large settlements, habits, historical experience, the traditional way of life of the rural population, the level of engineering development of the territory; the roads).

- Your suggestions to improve the level of provision of household and social needs of the population in your villages.

Experts in the formation of the issues made by scientists of the Omsk State Agrarian University and specialists of the Ministry of Agriculture and Food of the Omsk region.

In the study, it was surveyed from 5 to 10 people between the ages of 20 and 65 from each village. The research results allowed to identify the main factors influencing the development of social infrastructure in rural areas (table 2).

Table 2. Factors influencing the development of social infrastructure

\begin{tabular}{|l|c|}
\hline \multicolumn{1}{|c|}{ Factor } & $\%$ of respondents \\
\hline State agricultural policy & 9,5 \\
\hline The level of development of agricultural production & 14,2 \\
\hline Location of rural areas over the location of cities & 9,5 \\
\hline Habits, historical experience, the traditional way of life of the rural population & 4,8 \\
\hline Level of engineering development of the territory & 23,8 \\
\hline Roads & 38,2 \\
\hline
\end{tabular}


The main factors constraining the development of social infrastructure identified as roads and low engineering development of the territory. When respondents were asked about the changes in living conditions over the past 5 years, the following answers were obtained (table 3 ).

Table 3. Analysis of the responses to questions about the changes in the living conditions of the rural population, $\%$

\begin{tabular}{|l|c|c|c|}
\hline \multicolumn{1}{|c|}{ Factor } & deterioration & Without changes & improvement \\
\hline Terms of education of children & 42,8 & 38,1 & 19,1 \\
\hline Terms of raising children in preschool & 33,3 & 23,8 & 42,9 \\
\hline Medical service & 28,7 & 52,3 & 19,0 \\
\hline Cultural service & 38,1 & 47,6 & 14,2 \\
\hline Living conditions & 19,1 & 57,1 & 23,8 \\
\hline Supplying food products & 33,3 & 42,8 & 23,8 \\
\hline Supplying industrial goods & 42,8 & 38,1 & 19,1 \\
\hline Consumer services & 90,5 & - & 9,5 \\
\hline Availability of public transport & 28,6 & 57,1 & 14,3 \\
\hline
\end{tabular}

As can be seen from the data, more than $90 \%$ of respondents noted the deterioration of public services, more than $40 \%$ - deterioration in the terms of education and the supply of industrial goods. Living conditions in the bulk of the respondents remained unchanged, only $23 \%$ of respondents could improve their living conditions, while for $19 \%$ of respondents they will be only worse.

Reduction of social infrastructure objects in remote areas impacts negatively on their development and accompanied by a deterioration of transport services.

\section{Results of study}

The poll revealed significant needs in a range of social infrastructure facilities such as hairdressing salons, gas stations and others. Therefore, this study proposes the creation of mobile units to provide some of these essential everyday services. These mobile service units are intended to provide a range of social assistance and everyday services to residents of remote areas of the country. The basic model would include a hairdresser; repair, maintenance and servicing of household appliances; clothes repair and tailoring; and shoe repair. Social security and pension fund experts, lawyers, notaries, representatives of credit, trading, banking institutions, etc. can also work from mobile units. These mobile service units would operate most effectively with the creation of regional and interregional centers for social assistance and everyday services. The economic activity of the mobile units would involve implementation of the following costs in the context of services provided.

\section{Hairdressing salon.}

Investment costs for the creation of a mobile hairdressing salon are presented in Table 4.

Table 4. Investment costs of setting up mobile hairdressing salon units

\begin{tabular}{|l|c|c|c|}
\hline \multicolumn{1}{|c|}{ Expenses } & Pcs & $\begin{array}{c}\text { Price per piece, } \\
\text { USD. }\end{array}$ & Amount, USD. \\
\hline 1. Vehicle & 1 & 15384.61 & 15384.61 \\
\hline 2. Equipment (special rigging) for water supply & 5 & - & 92,31 \\
& & & \\
\hline 3. Heating, ventilation, air conditioning equipment & 1 & 284.62 & \\
\hline 4. Electrical supply and lighting equipment & 4 & - & 947.62 \\
\hline 5. Furniture and other special materials & 19 & - & 404.62 \\
\hline Total & $\mathrm{x}$ & $\mathrm{x}$ & 17113.85 \\
\hline
\end{tabular}




\section{Detailed interpretation of certain types of investment costs is presented in Appendix 1.}

\section{Current costs of creating a mobile hairdresser in a year constitute 19,397.07 dollars. Their composition, structure, and explanations are given in Appendix 2.}

The calculation of the expected profit is presented below.

The throughput capacity of one hairdresser is 20 pers./day. A working shift is 10 hours $(600 \mathrm{~min}$.) Throughput capacity of 1 specialist per year is the following:

20 pers. $/$ day $\cdot 247$ working days $=4,940$ pers.

Throughput capacity of 2 specialists per year:

40 pers. $/$ day $\cdot 247$ work days $=9,880$ pers.

The average price of the service provided is 2.31 USD. Revenue per annum ( 1 specialist):

$4.940 \cdot 2.31=11411.4 \mathrm{USD}$

Revenue per annum (2 specialists):

$9.880 \cdot 2.31=22822.8$ USD.

If there are two specialists in a mobile hairdresser, the time taken to serve the local population $(3,857$ people) would be three months. Let's estimate the effectiveness of this project using financial and economic indicators (Tables 3-5). The total expenses (investment and current) are presented in Table 5.

Table 5. Predicted returns on mobile hairdressing units in the first year

\begin{tabular}{|l|c|}
\hline \multicolumn{1}{|c|}{ Indicator } & Amount, USD \\
\hline Registration of an individual as a private entrepreneur & 12,31 \\
\hline Investment costs & 17113,85 \\
\hline Current expenses & 19397,07 \\
\hline Total cost in the first year & 36523,22 \\
\hline Revenue per annum & 22800 \\
\hline Profit (loss) & $(13723,22)$ \\
\hline
\end{tabular}

Table 6 calculates how long it will take for a mobile hairdressing unit to meet its setup costs.

Table 6. Predicted mid-term returns on mobile hairdressing units

\begin{tabular}{|l|c|c|c|c|c|}
\hline \multicolumn{1}{|c|}{ Indicators } & \multicolumn{4}{|c|}{ Payback period, years } \\
\cline { 2 - 5 } & 2015 & 2016 & 2017 & 2018 & 2019 \\
\hline Profit/ USD. & 3402,92 & 3675,38 & 39362,62 & 4168,62 & 4377,18 \\
\hline Investment costs/ USD. & 147113,85 & & & \\
\hline Cash flow on the project/ USD. & $-13710,92$ & $-10035,54$ & $-61012,92$ & $-1934,31$ & 2442,77 \\
\hline Payback period/ years & & & 4,4 & \\
\hline
\end{tabular}

According to this calculation, the costs of a mobile hairdressing unit would be repaid after 4.4 years. 
2. Repair, maintenance and servicing of household appliances; clothes repair and tailoring; and shoe repair Investment costs for setting up mobile service units for repair constitute 18,513.85 USD. (Table 7).

Table 7. Investment costs of setting up mobile repair units

\begin{tabular}{|c|c|c|c|}
\hline Expenses components & Pcs & $\begin{array}{c}\text { Price per piece, } \\
\text { USD. }\end{array}$ & Amount, USD. \\
\hline 2. Equipment (special rigging) for water supply & 5 & - & 92.31 \\
\hline 3. Heating, ventilation, air conditioning equipment & 1 & 284.6 & 284.6 \\
\hline 4. Electrical supply and lighting equipment & 4 & - & 947.69 \\
\hline 5. Furniture and other special materials & 19 & - & 1804.62 \\
\hline
\end{tabular}

Detail information of certain types of investment costs is presented in Appendix 3.

The calculation of the expected profit is presented below.

Current costs of setting up mobile location social purpose of repair in the first year of operation amounted to 18,025.9 USD. Their composition, structure, and explanations are given in Appendix 4.

The capacity of the mobile service - 30 people a day. Since the demand for these services are experienced by about $20 \%$ of the rural population (3875 persons.), the term of service of the rural population of Tarski district is 128 days.

Based on a working shift of 10 hours (600 min.), the throughput capacity of 1 specialist is 10 pers./day. The throughput capacity of 3 specialists would therefore be:

30 pers. $/$ day $\cdot 247$ work days $=7,410$ pers. $/$ year

The term of service of the rural population of Tarsky district is 128 days. This amounts to 1.9 turns per year (247 working days).

The average price of such services is 2.85 USD. Revenue per annum is:

$7,410 \cdot 2.85=21118.5$ USD

The predicted costs, revenue and profits of mobile repair units are presented in Table 8.

Table 8. Predicted returns on mobile repair units in the first year

\begin{tabular}{|l|c|}
\hline \multicolumn{1}{|c|}{ Indicator } & Amount, USD \\
\hline Registration of an individual as a private entrepreneur & 12.3 \\
\hline Investment costs & 18513.8 \\
\hline Current expenses & 18025.9 \\
\hline Total cost in the first year & 36552.1 \\
\hline Revenue per annum & 21090 \\
\hline Profit (loss) & $(15462.1)$ \\
\hline
\end{tabular}

Table 9 calculates how long it will take for mobile repair units to cover their setup costs. 
Table 9. Predicted mid-term returns on mobile repair units

\begin{tabular}{|l|c|c|c|c|c|}
\hline \multicolumn{1}{|c|}{ Indicators } & \multicolumn{5}{c|}{ Payback period, years } \\
\hline & 2015 & 2016 & 2017 & 2018 & 2019 \\
\hline Profit, USD & 3064.2 & 3307.7 & 3540.9 & 3753.4 & 3941.1 \\
\hline Investment costs, USD & 18513.8 & & & & \\
\hline Cash flow on the project, USD & -15449.7 & -12140.5 & -8599.5 & -4846.2 & -905.1 \\
\hline Payback period, years & & & & & 5.2 \\
\hline
\end{tabular}

According to this calculation, the project will be repaid after 5.2 years.

\section{Discussion of the results}

An assessment of the cost-effectiveness and feasibility of implementing a project investing in mobile hairdressing units is presented in Table 10. The forecast also examines the feasibility of implementing the investment project in 2016-2019.

Table 10. Assessment of cost-effectiveness and feasibility of implementing mobile hairdressing units

\begin{tabular}{|c|c|c|c|c|c|c|c|c|c|c|}
\hline $\begin{array}{c}\text { Year of } \\
\text { operation }\end{array}$ & Earnings, USD & $\begin{array}{c}\text { Project costs, } \\
\text { USD }\end{array}$ & Profit, USD & \multicolumn{7}{|c|}{ Evaluation of the budget effectiveness } \\
\hline \multicolumn{4}{|c|}{ Proprietary funds } & \multicolumn{6}{|c|}{ Target tax proceeds, USD. } & 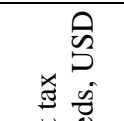 \\
\hline 2015 & & 14036.9 & & & \multirow{4}{*}{ 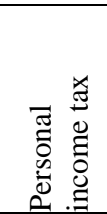 } & \multirow{4}{*}{ 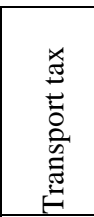 } & \multirow[b]{4}{*}{ ఫేّ } & \multirow{4}{*}{ 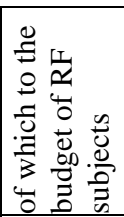 } & \multirow{4}{*}{ 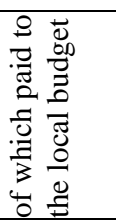 } & \multirow{4}{*}{ 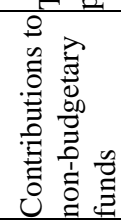 } \\
\hline \multicolumn{4}{|c|}{ Size of state support, USD } & $\Phi$ & & & & & & \\
\hline 2015 & & 3076.9 & &. $\bar{\Xi}$ & & & & & & \\
\hline \multicolumn{4}{|c|}{ Operating results, USD } & 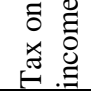 & & & & & & \\
\hline 2015 & 22800 & 19397.1 & 3402.9 & 168 & 1080 & 615.4 & 1288 & 958 & 330 & 2508.9 \\
\hline 2016 & 24624 & 20948.8 & 3675.4 & 181.4 & 1080 & 615.4 & 1301.4 & 958 & 343.4 & 2508.9 \\
\hline 2017 & 26347.7 & 22415.4 & 3932.6 & 194.2 & 1080 & 615.4 & 1314.2 & 958 & 356.2 & 2508.9 \\
\hline 2018 & 27929.2 & 23760.2 & 4168.6 & 205.8 & 1080 & 615.4 & 1325.8 & 958 & 367.8 & 2508.9 \\
\hline 2019 & 29324.9 & 24948.2 & 4377.1 & 216 & 1080 & 615.4 & 1336 & 958 & 378 & 2508.9 \\
\hline
\end{tabular}

Modern equipment, imported stocks of supplies and advanced sterilization equipment ensure the autonomous operation of a mobile laboratory complex for a long time. A mobile laboratory complex maintains comfortable working conditions at an ambient temperature of $-30^{\circ} \mathrm{C}$ to $+40^{\circ} \mathrm{C}$.

An assessment of the cost-effectiveness and feasibility of implementing an investment project to create mobile repair units is presented in Table 11.

According to the "Procedure for provision of subsidies at the expense of the regional budget to small and medium-sized businesses for financial support (compensation) for part of the costs associated with the implementation of socially important projects in the municipalities of Omsk region", found in the subprogram 
The International Journal

ENTREPRENEURSHIP AND SUSTAINABILITY ISSUES

ISSN 2345-0282 (online) http://jssidoi.org/jesi/

2018 Volume 5 Number 4 (June)

http://doi.org/10.9770/jesi.2018.5.3(4)

"Development of small and medium-sized enterprises in Omsk region" in the state program "Development of the economic potential of Omsk region" (approved by Resolution of the Government of Omsk region dated 10.16.2013 No. 266-P), a proportion of the investment costs might be covered by state support (subsidies).

Table 11. Assessment of cost-effectiveness and feasibility of implementing mobile repair units

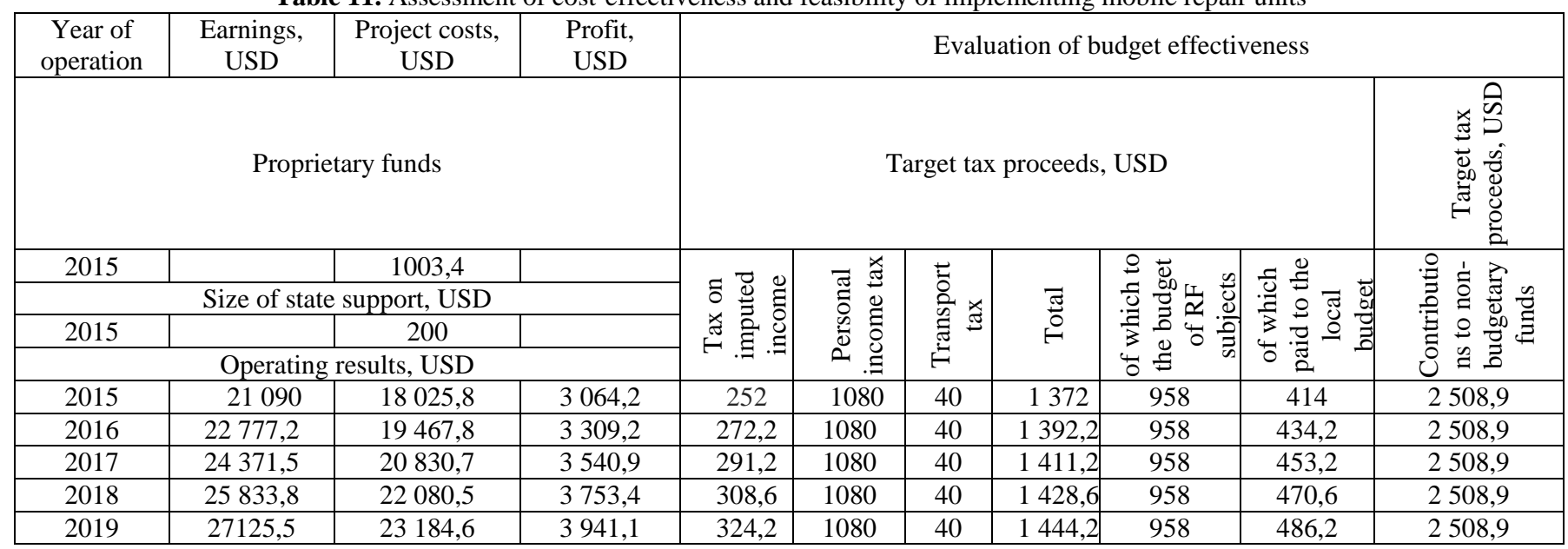

The amount of subsidy available is $90 \%$ of the planned expenses of a small business implementing a socially important project, to a value of not more than 15384.6 USD per business.

\section{Conclusion}

Social corporate responsibility has recently been given a lot of attention. The scope of public services plays an important role in the supporting everyday life and socio-economic development in various countries.

Based on an opinion poll which identified a significant need for better provision of everyday services such as hairdressing salons, repair shops and so on in remote regions of Western Siberia which are cut off from the roads during winter, the authors have proposed a model for an investment project to develop mobile units to provide such services and calculated their cost-effectiveness.

The calculations showed that the payback period on the projects would be 4.4 years for mobile hairdressing units and 5.2 years for mobile units offering for repairing of household appliances, footwear and clothing.

An important finding of the study is that the implementation of these projects, in addition to the economic benefit, will provide a significant social effects, such as:

- creating new jobs;

- satisfying the everyday needs of the population;

- improving the level of public services;

- improving the quality of life of isolated rural populations;

- increasing income levels;

- reducing unemployment;

- an increase in payments to local budgets. 
It is important to note that the achievement of this effect is related to the costs of certain business structures. However, the social effect also plays into the hands of these business structures in the future. This is confirmed in a number of scientific researches and is also in line with the state policy of many countries. Similarly it is important for Russia, as it promotes the adaptation of rural society to market conditions.

\section{Acknowledgments}

Research was supported by Russian Foundation for Basic Research according to the research project № 18-410550024 "Research of the system of indicators of the level and quality of life of the rural population, allowing to evaluate the results of social development of rural areas of the Omsk region".

\section{References}

Akhmetshin, E. M.; Barmuta, K. A.; Yakovenko, Z. M.; Zadorozhnaya, L. I.; Mironov, D. S.; Klochko, E. N. 2017. Advantages of cluster approach in managing the economy of the Russian Federation. International Journal of Applied Business and Economic Research, 15(23): 355-364.

Akhmetshin, E. M.; Osadchy, E. A. 2015. New requirements to the control of the maintenance of accounting records of the company in the conditions of the economic insecurity, International Business Management, 9(5): 895-902.

A Renewed EU Strategy 2011-14 for Corporate Social Responsibility, 2011. European Commission.

Decree of the Government of the Russian Federation "O strategii ustoychivogo razvitiya selskikh territoriy Rossiyskoy Federatsii na period do 2030 goda" [On the strategy of sustainable development of rural territories of the Russian Federation for the period through to 2030] of 02.02.2015 \#151-r.

Decree of the Government of the Russian Federation "Ob utverzhdenii gosudarstvennoy programmy Rossiyskoy Federatsii 'Razvitiye transportnoy sistemy" [On approval of the state program of the Russian Federation "Development of the transport system"] of 15.04.2014 \#319.

Federal Law “Ob obshchikh printsipakh organizatsii mestnogo samoupravleniya v Rossiyskoy Federatsii” [On general principles for the organization of local government in the Russian Federation] of 06.10.2003 \#131-FZ (as amended on 03.11.2015).

Frolova E.V., Rogach O.V. Municipal-private partnership in education: infrastructural aspect. Economic and Social Changes: Facts, Trends, Forecast, 2017, vol. 10, no. 1, pp. 145-160. https://doi.org/10.15838/esc/2017.1.49.8

Urzha O.A. (2017). Social Engineering - as Methodology of Management Activity. Sotsiologicheskie Issledovaniya Issue: 10 Pages: $87-$ 96. https://doi.org/10.7868/S0132162517100099

Glass, G.D.; O'Brien, D.J. 2016. The role of household social organization in the structure of rural economies: comparing forest resource dependent and agriculturally dependent regions in Russia, Rural Sociology 81(4): 635-54. https://doi.org/10.1111/ruso.12109

Granberg, L. 2016. Long wave of rural research from combating poverty to sustaining ecosystems, Research in rural sociology and development, 23: 69-91.

GREEN PAPER: Promoting a European framework for Corporate Social Responsibility, 2001. Office for Official Publications of the European Communities. European Commission.

Marsat, S.; Williams, B. 2014. Does the market value Social Pillar? Available on the Internet: www.efmaenn.org/0EFMAMEETINGS/EF MA\%20ANNUAL\%20MEETINGS/2014-Rome/papers/EFMA2014_0296_fullpaper.pdf

Moser, D.V.; Martin, P.R. 2012. A Broader perspective on Corporate Social Responsibility research in accounting, The Accounting Review, 87(3): 797-806. https://doi.org/10.2308/accr-10257

Nardin, D.S.; Shumakova, O.V.; Novikov, Yu. I.; Blinov, O.A.; Nardina, S.A. 2015. Rating of a rural tourism potential of rural territories], Biosciences Biotechnology Research Asia, 12(3): 2731-2738. http://dx.doi.org/10.13005/bbra/1955 
Poltorykhin, M.V.; Shumakova, O.V.; Rabkanova, M.A. 2015. Problemy ustoychivogo razvitiya selskikh territoriy [Problems of sustainable development of rural territories]. Omsk: GASU PPD, 196.

Resolution of the Government of Omsk region "Ob utverzhdenii gosudarstvennoy programmy Omskoy oblasti "Razvitiye transportnoy sistemy Omskoy oblasti" [On approval of the state program of Omsk region "Development of transport system of the Omsk region"] of 16.10.2013 \#262-P.

Resolution of the Government of Omsk region "Ob utverzhdenii gosudarstvennoy programmy Omskoy oblasti "Razvitiye ekonomicheskogo potentsiala Omskoy oblasti"" [On approval of the state program of Omsk region "Development of the economic potential of Omsk region"] of 10.16.2013 \#266-P.

Shainyan, B.R. 2007. 'Analiz zarubezhnogo opyta razvitiya bytovogo obsluzhivaniya' [Analysis of foreign practice of development of consumer services], Rossiyskoye Predprinimatelstvo, 10-2(100): 169-173. www.creativeconomy.ru/articles/12238/

Shannon, D. et al. 2009. Richard Posner's Theory of Wealth Maximization from Efficiency Instead of Justice? New York: Springer Netherlands, 143-183.

Shumakova, O.; Yakubenko, M.N.; Blinov, O.A.; Remizova, A.A.; Rabkanova, M.A.; Mozzherina T.G.; Gapon M.N. 2012. Ustoychivoye razvitiye selskikh territoriy (na materialakh Omskoy oblasti) [Sustainable development of rural territories (on the materials of Omsk region)]. Omsk: Publishing House of VPO OmSAU named after P.A. Stolypin, 364.

Shumakova, O.V.; Blinov, O.A.; Nardin, D.S.; Kosenchuk, O.V.; Yakubenko, M.N.; Novikov, Yu.I.; Remizova, A.A.; Rabkanova, M.A.; Kryukova O.N. 2015. Razvitiye agroturizma v Omskoy oblasti [Development of agro-tourism in Omsk region]. Omsk: Litera, 158.

Svetlanská, T.; Turčeková, N.; Adamičková, I.; Skalský, R. 2017. Food security facets: case of Slovakia regions, Journal of Security and Sustainability Issues 7(2): 311-320. https://doi.org/10.9770/jssi.2017.7.2(11)

Tvaronavičienè, M. 2018. Towards sustainable and secure development: energy efficiency peculiarities in transport sector, Journal of Security and Sustainability Issues 7(4): 719-725. https://doi.org/10.9770/jssi.2018.7.4(9)

Velikii, P.P.; Morekhina, M.Iu. 2006. The adaptive potential of rural society, Sociological Research 45(6): 51-67. http://dx.doi.org/10.2753/SOR1061-0154450603

Wegren, S.K. 2016. The quest for rural sustainability in Russia, Sustainability 8(7): 1-18. http://dx.doi.org/10.3390/su8070602

Wegren, S.K.; Nikulin, A.M.; Trotsuk, I. 2017. The Russian variant of food security, Problems of post-communism 64(1): 47-62. https://doi.org/10.1080/10758216.2016.1163229

Wegren, S.K.; Nilssen, F.; Elvestad, C. 2016. The impact of Russian food security policy on the performance of the food system, Eurasian geography and economics 57(6): 671-699. https://doi.org/10.1080/15387216.2016.1222299

\section{Appendix 1}

Auxiliary equipment and support systems include:

Water supply: water tank 50-801 (6,2 USD), stainless steel sink (10,8 USD); pump for the water supply 12V (15,4 USD); electric heater 151 (35,4-53,8 USD); canister for collecting the used water 301 (6,2 USD). Heating, ventilation and air conditioning: additional heater (284,6 USD). Lighting: strip lights $220 \mathrm{~V}$ (2 pcs.) (3,7 USD).

Electricity supply: diesel generator (1000 USD); device to connect an external power supply 220V (electric cable 30m) (6,2 USD); outlet to connect equipment (3,1 USD); car refrigerator (61,5 USD). Furniture and other special materials: wardrobe with two compartments (76,9 USD); hanging closet for supplies (30,8 USD); pedestal tables with drawers (76,9 USD); shelving for storage of equipment and supplies (46,2 USD); folding table in the passenger compartment (15,4 USD); soap dispenser (1,5 USD); paper towel holder ( 3,1 USD); hair dyeing brush, combs, scissors (30,8 USD); special tools (hair dryer, curling irons) (107,7 USD); uniform (15,4 USD).

Appendix 2

Table. Current costs of setting up a mobile hairdressing unit in the first year of operation

\begin{tabular}{|l|c|c|}
\hline \multicolumn{1}{|c|}{ Expenses components } & Price per piece, USD & Annual cost, USD. \\
\hline 1. Supplies (hair dye, eyebrow dye, oxidizers, balms, foil and other supplies) & - & 3538,46 \\
\hline 2. Labor expenses (3 pers.) & $230,77 /$ month & 8307,69 \\
\hline
\end{tabular}




\begin{tabular}{|c|c|c|}
\hline 3. Depreciation of vehicle & - & 2197,8 \\
\hline 4. POL & - & 2020,77 \\
\hline 6. Taxes and charges (transport, UTII) & - & 2716,97 \\
\hline Total & - & 19397,07 \\
\hline
\end{tabular}

A PAZ 32053 bus - 130 horsepower at 3,200 rpm - is in the fourth depreciation group of 5 to 7 years. Transport tax is 40 USD, UTII is 168,04 USD. Contributions to non-budget funds amount to 2508,92 USD. The standard fuel consumption of a PAZ 32053 at $60 \mathrm{~km} / \mathrm{h}$ is 20 litres $/ 100 \mathrm{~km}$. The cost of $92 \mathrm{RON}$ gasoline is, at the time of writing, 0,5 USD/litre.

\section{Appendix 3 \\ Auxiliary equipment and support systems include:}

Water supply: water tank 50-801 (6,2 USD), stainless steel sink (10,8 USD); pump for the water supply 12V (15,4 USD); electric heater 151 (35,4-53,8 USD); canister for collecting used water 301 (6,2 USD).

Heating, ventilation and air conditioning: additional heater (284,6 USD) Lighting: strip lights $220 \mathrm{~V}$ (2 pcs.) (3,69 USD). Electricity supply: diesel generator (876,92 USD); device to connect an external power supply $220 \mathrm{~V}$ (electric cable $30 \mathrm{~m})(6,15 \mathrm{USD})$; outlet to connect equipment (3,08 USD); car refrigerator (61,54 USD).

Furniture and other special materials: wardrobe with two compartments (76,92 USD); hanging closet for supplies (30,77 USD); pedestal tables with drawers (76,92 USD); shelving for storage of equipment and supplies (46,15 USD); folding table in the passenger compartment (17,5 USD); soap dispenser (3,08 USD); paper towel holder (3,08 USD); uniform (15,38 USD); other materials (yarn, fabric, scissors, screwdrivers, glue, etc.) (769,23 USD); special tools for shoe repair (538,46 USD).

\section{Appendix 4}

Table. Current costs of setting up a mobile unit of social and everyday purposes for repair in the first year of operation

\begin{tabular}{|l|c|c|}
\hline \multicolumn{1}{|c|}{ Expenses components } & Price breakdown, USD. & Annual costs, USD. \\
\hline 1. Materials (yarn, fabric, glue, etc.) & - & 1538,46 \\
\hline 2. Labor expenses (3 pers.) & $230,77 / \mathrm{month}$ & 8307,69 \\
\hline 3. Depreciation of vehicle & - & 2197,8 \\
\hline 4. POL & - & 2104,04 \\
\hline 5. Vehicle repair and maintenance & - & 307,69 \\
\hline 6. Taxes and charges (transport, UTII) & - & 2800,99 \\
\hline 7. Other expenses & - & 769,23 \\
\hline \multicolumn{1}{|c|}{ Total } & - & 18025,9 \\
\hline
\end{tabular}

Transport tax is 81,25 USD.

UTII is 252,07 USD.

Contributions to non-budget funds would amount to 2 508,92 USD.

Oksana Viktorovna SHUMAKOVA, doctor of Economics, Professor Omsk State Agrarian University named after P.A. Stolypin, department of Economics, accounting and financial control, Russian Federation, 644008, Omsk, 1 Institutskaya pl. ORCID ID: 00000002-2228-5014

Marina Nikolaevna GAPON, PhD, associate Professor. Omsk State Agrarian University named after P.A. Stolypin, department of Economics, accounting and financial control, Russian Federation, 644008, Omsk, 1 Institutskaya pl. ORCID ID: 0000-0002-0354-6098

Oleg Anatolyevich BLINOV, PhD, associate Professor. Omsk State Agrarian University named after P.A. Stolypin, department of Economics, accounting and financial control, Russian Federation, 644008, Omsk, 1 Institutskaya pl. ORCID ID: 0000-0002-8947-5963

Vitaly Yuryevich EPANCHINTSEV, PhD, associate Professor. Omsk State Agrarian University named after P.A. Stolypin, department of Economics, accounting and financial control, Russian Federation, 644008, Omsk, 1 Institutskaya pl. ORCID ID: 0000-0002-5616-8123

Yury Ivanovich NOVIKOV, PhD, associate Professor. Omsk State Agrarian University named after P.A. Stolypin, department of Economics, accounting and financial control, Russian Federation, 644008, Omsk, 1 Institutskaya pl. ORCID ID: 0000-0002-2049-4381 